\title{
Early Detection of Colorectal Cancer, Is It a Guarantee for the Cure of Cancer?
}

\author{
Kang Young Lee \\ Department of Surgery, Yonsei University College of Medicine, Seoul, Korea
}

\section{See Article on Page 49-55}

For the last several decades, the prognosis for colorectal cancer has improved. All aspects of colorectal cancer treatments, including new chemotherapeutic drugs and standardization of surgical treatment, have contributed to this improvement in survival. Among them, the most important contribution is early detection of cancer through screening programs, followed by a curative resection of the tumor. Even though early detection of the cancer and a curative resection offer the best chance for a cure, still $10 \%$ of the tumors will recur after treatment for early colorectal cancer $[1,2]$.

Some clinicopathologic parameters, such as an infiltrative growth pattern of the tumor, lymphovascular invasion, and tumor budding, have been suggested as risk factors for treatment failure in early colorectal cancer. Pathologically, tumor budding is defined as a single cell or a small cluster of cells away from the tumor mass. Tumor budding is regarded as not only a prognostic factor in early and advanced colorectal cancer, but also a risk factor of regional lymph nodes metastasis [3], and Keum et al. [4] found tumor budding in a primary tumor, for which recurrence was diagnosed during follow-up. Lymphovascular invasion has also been reported as an independent risk factor for regional lymph nodes metastasis and as an independent prognostic factor in the management of early colorectal cancer [5]. There is no doubt that patients with these risk factors should be followed with careful attention.

In a study by Keum et al. [4], the recurrence pattern after a curative resection for early colorectal cancer was described.

Correspondence to: Kang Young Lee, M.D.

Department of Surgery, Yonsei University College of Medicine, 50 Yonsei-ro, Seodaemun-gu, Seoul 120-749, Korea

Tel: +82-2-2019-3370, Fax: +82-2-3462-5994

E-mail: kylee117@yuhs.ac

(c) 2012 The Korean Society of Coloproctology

This is an open-access article distributed under the terms of the Creative Commons Attribution NonCommercial License (http://creativecommons.org/licenses/by-nc/3.0) which permits unrestricted noncommercial use, distribution, and reproduction in any medium, provided the original work is properly cited.
Interestingly, locoregional recurrence was observed only in rectal cancer. The anastomosis site, the presacral area, and the pelvic wall were the places of locoregional recurrence. This result might reflect the importance of complete total mesorectal excision in the management of rectal cancer, even in cases of early cancer.

Even in early colorectal cancer, patients with adverse clinicopathologic characteristics have a risk of treatment failure, so close follow-up is mandatory for these patients. In another aspect, the validation of molecular biological markers as prognostic factors should be mentioned. Since the clinicopathologic characteristics of the primary tunor are phenotypes of its biological characteristics, precise evaluation of molecular biological characteristics could be the next era of research on risk assessment for early colorectal cancer.

\section{REFERENCES}

1. Blumberg D, Paty PB, Picon AI, Guillem JG, Klimstra DS, Minsky BD, et al. Stage I rectal cancer: identification of high-risk patients. J Am Coll Surg 1998;186:574-9.

2. Wichmann MW, Müller C, Hornung HM, Lau-Werner U, Schildberg FW; Colorectal Cancer Study Group. Results of long-term follow-up after curative resection of Dukes A colorectal cancer. World J Surg 2002;26:732-6.

3. Wang LM, Kevans D, Mulcahy H, O'Sullivan J, Fennelly D, Hyland J, et al. Tumor budding is a strong and reproducible prognostic marker in T3N0 colorectal cancer. Am J Surg Pathol 2009; 33:134-41.

4. Keum MA, Lim SB, Kim SA, Yoon YS, Kim CW, Yu CS, et al. Clinicopathologic factors affecting recurrence after curative surgery for stage I colorectal cancer. J Korean Soc Coloproctol 2012; 28:49-55.

5. Iida S, Hasegawa H, Okabayashi K, Moritani K, Mukai M, Kitagawa Y. Risk factors for postoperative recurrence in patients with pathologically T1 colorectal cancer. World J Surg 2012;36:424-30. 